\title{
Influence of processing and storage of integral grape juice (Vitis labrusca L.) on its physical and chemical characteristics, cytotoxicity, and mutagenicity in vitro
}

E. Düsman ${ }^{1}$, I.V. Almeida ${ }^{2}$, E.P. Pinto ${ }^{3}$, L. Lucchetta $^{3}$ and V.E.P. Vicentini ${ }^{2}$

${ }^{1}$ Departamento Acadêmico de Química e Biologia, Universidade Tecnológica Federal do Paraná, Francisco Beltrão, PR, Brasil

${ }^{2}$ Departamento de Biotecnologia, Genética e Biologia Celular, Universidade Estadual de Maringá, Maringá, PR, Brasil

${ }^{3}$ Departamento Acadêmico de Engenharia de Alimentos, Universidade Tecnológica Federal do Paraná, Francisco Beltrão, PR, Brasil

Corresponding author: E. Düsman

E-mail: edusman@utfpr.edu.br

Genet. Mol. Res. 16 (2): gmr16029670

Received March 16, 2017

Accepted April 27, 2017

Published May 31, 2017

DOI http://dx.doi.org/10.4238/gmr16029670

Copyright $(2017$ The Authors. This is an open-access article distributed under the terms of the Creative Commons Attribution ShareAlike (CC BY-SA) 4.0 License.

\begin{abstract}
Integral grape juice is extracted from the grape through processes that allow the retention of their natural composition. However, due to the severity of some processes, fruit juices can undergo changes in their quality. The present study evaluated the cytotoxic and mutagenic effects of integral grape juice by a cytokinesis-blocked micronucleus assay in Rattus norvegicus hepatoma cells (HTC) in vitro. Vitis labrusca L. (variety Concord) were produced organically and by a conventional system, and their juice was extracted by a hot extraction process. The organic grapes were subjected to ultraviolet-type C radiation (UV-C). Experiments were performed after production and after 6 months in storage. Physicochemical analyses revealed that UV-C irradiation of
\end{abstract}

Genetics and Molecular Research 16 (2): gmr16029670 
organic grapes, the juice production process, and storage resulted in nutraceutical alterations. However, none of the juice concentrations were cytotoxic to HTC cells by the cytokinesis-blocked proliferation index results or were mutagenic, because the formation of micronucleated cells was not induced. In general, juice induced cell proliferation, possibly due to the presence of vitamins and sugar content (total soluble solid). The data increased the understanding of food technology and confirmed the quality and safety consumption of these juices.

Key words: Antioxidants; Food technology; Metabolizing cell lines; Nutraceutical alterations; Hepatoma cells of Rattus norvegicus; Micronucleus

\section{INTRODUCTION}

Grapevines (Vitis spp) are considered to be some of the most important fruit species, mainly due to the uses of the grape in wine production, grape juice, and other foods and because the grape is an excellent source of phenolic compounds (Ali et al., 2010).

Integral grape juice is a clear or cloudy liquid extracted from grapes through processes that retain their natural concentration and composition without the addition of sugar (Rizzon et al., 1998). Then, integral grape juice is rich in flavonols, anthocyanins, phenolic acids, hydroxycinnamic and hydroxybenzoic acids, resveratrol, glucose, fructose, amino acids, polypeptides, proteins, tartaric acid, malic acid, citric acid, vitamins such as thiamine, riboflavin, niacin, ascorbic acid, and inositol, and mineral elements such as potassium, sodium, calcium, magnesium, phosphorus, iron, manganese, copper, zinc, lithium, and rubidium (Melo et al., 2016; Nassiri-Asl and Hosseinzadeh, 2016; Singh et al., 2016).

However, due to the severity of some technological processes or due to the storage period, fruit juices can undergo extensive changes, and as a result, their characteristics may be modified or may generate substances that can cause damage to DNA, cells, metabolism of the body. Research has shown that anthocyanins, which are present in grapes, are quickly destroyed by heat during processing and by storage (Malacrida and Motta, 2006) and that heat treatment is the most destructive step during processing (Tagliazucchi et al., 2013). Moreover, during the storage period, antioxidants may auto-oxidize to form reactive oxygen species that can be mutagenic (Kaya et al., 2002).

Organic products are perceived to be safer and healthier than those produced by conventional agriculture. However, studies conflict on the influence of these systems of production on the nutritional quality of foods. Some studies show an increase of bioactive compounds in organic foods (Olsson et al., 2006) and others do not note any change (Kalinova and Vrchotova, 2011). Another factor that influences the content of bioactive compounds from grapes is the ultraviolet-type $\mathrm{C}$ radiation (UV-C). This radiation produces an abiotic stress in plant tissues and affects the secondary metabolism in different ways, for example, in the synthesis of resveratrol and flavonoids (Cantos et al., 2001).

Therefore, it is important to assess the risk caused by chemical exposure in human diets, assisting in the development of safe food standards. Thus, the National and Federal Regulatory Agencies highlight the use of the micronucleus test with mammalian cells, especially using the metabolizing cell lines, such as hepatoma cells of Rattus norvegicus (HTC; COM, 2011).

Genetics and Molecular Research 16 (2): gmr16029670 
Thus, in addition to studies, which assess the influence of processing, storage, and production system on the physical and chemical characteristics of foods (especially juices), studies on food security assessment through the mutagenicity and cytotoxicity assays are needed. So, this study evaluated the effects of grape juices produced by conventional and organic farming under the action of UV-C radiation on cytotoxicity and mutagenicity, after production and after 6 months of storage in metabolizing cells of Rattus norvegicus in vitro. These data can help ensure the quality and safety of this juice after these processes, supporting consumption without harming human health.

\section{MATERIAL AND METHODS}

\section{Cell line - HTC}

HTC cells derived from a Rattus norvegicus hepatoma were obtained in the Cell Bank in Rio de Janeiro, Brazil. The cells were grown in $25-\mathrm{cm}^{2}$ culture flasks containing $10 \mathrm{~mL}$ DMEM culture medium (Invitrogen, Carlsbad, CA, USA) supplemented with $10 \%$ fetal bovine serum (Invitrogen) and incubated at $37^{\circ} \mathrm{C}$. The cell cycle in this cell line is approximately $24 \mathrm{~h}$.

\section{Treatment solution}

The grapes used in this study are Vitis labrusca L. variety Concord cultivated in Verê, which belongs to the microregion of Francisco Beltrão in the southwest region of Paraná, Brazil, in a subtropical climate, in the year of 2011. The grapes were obtained from two properties, one utilizing conventional growing practices $\left(25^{\circ} 54^{\prime} 01^{\prime \prime} \mathrm{S}\right.$ and $52^{\circ} 53^{\prime} 51^{\prime \prime} \mathrm{W}$ at an altitude of $564 \mathrm{~m})$ and a second with organic growing practices $\left(25^{\circ} 51^{\prime} 21^{\prime \prime} \mathrm{S}\right.$ and $52^{\circ} 55^{\prime} 06^{\prime \prime} \mathrm{W}$ at an altitude of $492 \mathrm{~m}$ ).

In the conventional system, chemical fertilizer on the soil and fungicides for the control of fungi were used. In the organic system, the soil had a green roof and copper sulfate, calcium hydroxide, and sulfur used for disease control.

The grapes were selected according to their degree of sanity, washed in chlorinated water $(50 \mathrm{mg} / \mathrm{L}$ sodium hypochlorite, $\mathrm{pH} 5.0)$ and refrigerated $\left( \pm 5^{\circ} \mathrm{C}\right)$.

The organic grapes were subjected to UV-C treatment by the method described by Cantos et al. (2001). We used the following parameters: radiation fluency rate of $65.6 \mathrm{~J} / \mathrm{m}^{2}$ and a distance of $30 \mathrm{~cm}$ from the light source. The organic grapes were arranged in a single layer on trays that were irradiated in a cabin equipped with three UV-C lamps (Philips ${ }^{\circledR} 90 \mathrm{~W}$ ) for 5 $\min$. Bunches were rotated $180^{\circ}$, and the light source remained on for another $5 \mathrm{~min}$ for a total irradiation time of $10 \mathrm{~min}$. The irradiated organic grapes were stored for 3 days at $25^{\circ} \pm 5^{\circ} \mathrm{C}$, $70 \%$ humidity, in the absence of light to promote the biosynthesis of bioactive compounds.

The integral juice was obtained by a hot extraction process at $90^{\circ} \mathrm{C}$ and stocked in glass bottles and stored in the dark for 6 months. In vitro evaluation and physicochemical analysis of conventional juice, organic juice, and organic juice of grapes treated with UV-C were performed immediately after the production (time 0 ) and after 6 months of juice storage.

\section{Ethics statements}

The grapes used in this study were provided by farmers, which gave permission

Genetics and Molecular Research 16 (2): gmr16029670 
to conduct the study on your private land. Besides this, the field studies did not involve endangered or protected species.

\section{In vitro evaluation}

\section{Cytokinesis-blocked micronucleus assay}

The cells $\left(10^{6}\right)$ were grown for $24 \mathrm{~h}$ in flasks containing $5 \mathrm{~mL}$ culture medium. Following this initial incubation, the cells were incubated with Cytochalasin B (98\%, CAS 14930-96-2, Sigma, St. Louis, MO, USA; $3.0 \mu \mathrm{g} / \mathrm{mL}$ culture medium for $26 \mathrm{~h}$ ) and with the treatment solutions $(24 \mathrm{~h})$ to evaluate their cytotoxicity and mutagenicity as described by Fenech (2000). Concentrations of 2, 10, and $20 \mu \mathrm{L}$ conventional juice, organic juice, and organic juice from grapes treated with UV-C per $\mathrm{mL}$ of culture medium at time 0 (immediately after production) and after 6 months of juice storage were tested. As a negative control, $20 \mu \mathrm{L}$ phosphate-buffered saline (PBS) per $\mathrm{mL}$ of culture medium was added. The positive control was doxorubicin (DOX, 98\%, CAS 25316-40-9) (Akcros, New Brunswick, NJ, USA) at a final concentration of $0.2 \mu \mathrm{g} / \mathrm{mL}$ culture medium.

After $24 \mathrm{~h}$ of treatment, the cells were harvested according to a previously published protocol by Salvadori et al. (2003). Briefly, the cells were trypsinized (500 $\mu \mathrm{L}$ trypsin- $0.025 \%$ EDTA; Gibco at $37^{\circ} \mathrm{C}$ ), pre-fixed with a drop of formaldehyde, centrifuged at $1000 \mathrm{rpm}$ for 5 min, hypotonized ( $1.5 \mathrm{~mL} \mathrm{1 \%}$ sodium citrate), centrifuged again and fixed (5 mL of a $3: 1$ mixture methanol:acetic acid). The slides were prepared with1 drop of the material collected on the blade, coated with a film of cold distilled water, stained with Giemsa (5\%), and refrigerated.

We selected binucleated cells, identified micronuclei, and calculated the cytokinesisblocked proliferation index (CBPI) as described by Fenech (2000). All experiments were performed in three biological replicates. To assess the frequency of binucleated cells with micronuclei (BCMN), 3000 binucleated cells were analyzed per treatment, and 1500 cells were counted to determine the CBPI, according to the following formula: CBPI $(\%)=$ number of mononuclear cells $(\mathrm{x} 1)+\mathrm{Bi}(\mathrm{x} 2)+$ multi $(\mathrm{x} 3) /$ total number of cells. The percentage of cytostasis was calculated by the following formula (OECD, 2010): \% cytostasis $=100-100$ $\left[\left(\mathrm{CBPI}_{\text {Treatment }}-1\right) \div(\mathrm{CBPI} \mathrm{Control}-1)\right]$.

\section{Physicochemical analysis}

\section{Total soluble solids, total titratable acidity, $\mathrm{pH}$, and color}

The determination of total soluble solids, total titratable acidity, and $\mathrm{pH}$ of juices (conventional, organic, and organic from grapes treated with UV-C) were performed according to the methods described by Instituto Adolfo Lutz (2008).

Instrumental color analysis of juices (conventional, organic, and organic from grapes treated with UV-C) was performed with a colorimeter (Minolta CR-300). The juices were placed on Petri dishes with $5 \mathrm{~cm}$ in diameter and $2 \mathrm{~cm}$ in height and color parameters were measured: $\mathrm{L}^{*}, \mathrm{a}^{*}$, and $\mathrm{b}^{*}$, where $\mathrm{L}^{*}$ indicates the lightness $(0=$ black and $100=$ white $)$ and $\mathrm{a}^{*}$ and $\mathrm{b}^{*}$ represent chromaticity coordinates $\left(+\mathrm{a}^{*}=\right.$ red, $-\mathrm{a}^{*}=$ green, $+\mathrm{b}^{*}=$ yellow, $-\mathrm{b}^{*}=$ blue $)$. Color parameters were converted into hue angle, $\mathrm{H}^{\circ}=\tan -1\left(\mathrm{~b}^{*} / \mathrm{a}^{*}\right)$, indicating Hue angle $\left(\mathrm{H}^{\circ}\right)$ of the sample $\left(0^{\circ}\right.$ or $360^{\circ}=$ red, $90=$ yellow, $180=$ green, $270=$ blue $)($ Zhang et al., 2008).

Genetics and Molecular Research 16 (2): gmr16029670 


\section{Total phenol compounds}

The total phenolic compound content of juices (conventional, organic, and organic from grapes treated with UV-C) was determined by the colorimetric method based by Singleton and Rossi (1965). A 1-mL aliquot of each juice, $60 \mathrm{~mL}$ ultrapure water and $5 \mathrm{~mL}$ Folin- Ciocalteu reagent were added to a 100-mL volumetric flask. After $8 \mathrm{~min}, 20 \mathrm{~mL} \mathrm{20 \%}$ sodium carbonate solution was added, and the volume was brought to $100 \mathrm{~mL}$ with ultrapure water. This mixture was stored away from light for $2 \mathrm{~h}$ and filtered. The absorbance of each sample at $725 \mathrm{~nm}$ was measured in a spectrophotometer Femto 800XI. Preliminary analyses of the samples showed high levels of phenolic compounds, and the samples were diluted 2.5 times. The results are reported as $\mathrm{mg}$ gallic acid equivalent/100 $\mathrm{mL}$ juice.

\section{Anthocyanins contents}

The total anthocyanin content of juices (conventional, organic, and organic from grapes treated with UV-C) was measured by the $\mathrm{pH}$ difference method according to Lee et al. (2005). Dilutions of each juice samples were made in a $50-\mathrm{mL}$ volumetric flask with a $\mathrm{pH} 1.0$ buffer solution and were read at $520 \mathrm{~nm}$ in a spectrophotometer Femto 800XI. We determined the absorbance of the samples diluted with buffer solution $\mathrm{pH} 1.0$ and $\mathrm{pH} 4.5$, at wavelengths of 520 and $700 \mathrm{~nm}$, respectively. The results are reported as $\mathrm{mg}$ cyanidin-3-glucoside/100 $\mathrm{mL}$ juice.

\section{Antioxidant activity}

The antioxidant activity of juices (conventional, organic, and organic from grapes treated with UV-C) was determined for four dilutions of each sample of juice by the DPPH method (2,2-diphenyl-1-picrylhydrazyl) as described by Brand-Wiliams et al. (1995), with modifications as in Rufino et al. (2007). A $0.1-\mathrm{mL}$ aliquot of each dilution was added to test tubes with $3.9 \mathrm{~mL}$ of the DPPH radical, and the control solution consisted of $0.1 \mathrm{~mL}$ methyl alcohol, acetone, and water. The homogenization was carried out in shaker tubes. After 30 min of reaction, absorbance was measured at $515 \mathrm{~nm}$ with a spectrophotometer Femto 800XI. Quantifications were based on a standard curve at concentrations of 10, 20, 30, 40, 50, and $60 \mu \mathrm{M}$, from an initial DPPH solution $(60 \mu \mathrm{M})$. The results are reported as $\mathrm{EC}_{50}(\mathrm{~mL}$ juice $/ \mathrm{g}$ $\mathrm{DPPH})$; that is, the values obtained correspond to the quantity of sample required to reduce the initial concentration of DPPH radical by $50 \%$.

Besides, the free radical scavenging activity was determined from a standard curve of Trolox (6-hydroxy-2,5,7,8-tetramethylchroman-2-carboxylic acid). Solutions were prepared at concentrations of $0.1,0.5,1.0,2.0$, and $3.0 \mu \mathrm{M}$ from an initial $20 \mu \mathrm{M}$ Trolox solution. For each concentration, 20,100, 200, 300, and $600 \mu \mathrm{L}$ were transferred to test tubes, and 4 $\mathrm{mL}$ DPPH solution was added; the test tubes were shaken, and their absorbance at $515 \mathrm{~nm}$ was measured in a spectrophotometer Femto 800XI after $30 \mathrm{~min}$ of reaction. The results are reported in Trolox equivalent antioxidant activity (TEAC) in $\mu \mathrm{M} / \mathrm{mL}$ juice.

\section{Statistical analysis}

Statistical analysis of the mean number of BCMN, the CBPI, the mean values of $\mathrm{pH}$, total soluble solids, total titratable acidity, total phenolic compounds, anthocyanins,

Genetics and Molecular Research 16 (2): gmr16029670 
antioxidant activity by $\mathrm{EC}_{50}$, and Trolox methodology and color, was carried out by analysis of variance (one-way ANOVA), followed by the Tukey test $(\alpha=0.05, \mathrm{P}<0.05, \mathrm{~N}=3$ ), by the GraphPad InStat Program.

\section{RESULTS AND DISCUSSION}

The results in Figure 1 show that no concentration $(2,10$, or $20 \mu \mathrm{L} / \mathrm{mL})$ of the juice that was evaluated (conventional, organic, or organic from grapes treated with UV-C) significantly induced the formation of micronucleated cells given that their BCMN values were similar to the negative control by the Tukey test. Moreover, the highest concentration $(20 \mu \mathrm{L} / \mathrm{mL})$ of organic grape juice (time 0 ) and conventional grape juice (6 months) presented an average number of micronucleated cells 2.5 times lower than that found for the mutagen DOX.

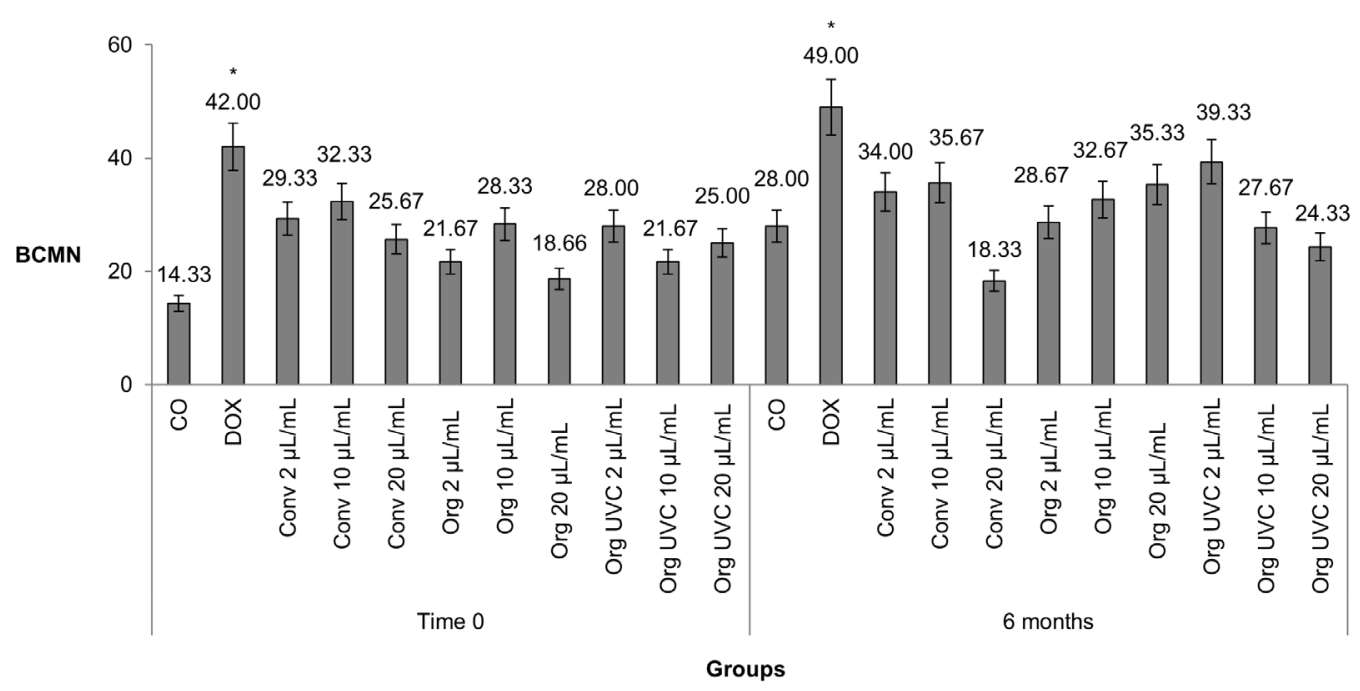

Figure 1. Mean and standard deviation of the number of binucleated cells with micronuclei (BCMN) of negative control (CO) $(20 \mu \mathrm{L}$ PBS) and groups treated with doxorubicin (DOX; $0.2 \mu \mathrm{g} / \mathrm{mL}$ ), integral grape juice from conventional grapes (Conv), organic grapes (Org), and organic grapes after treatment with UV-C (Org UVC) (2, 10 , and $20 \mu \mathrm{L} / \mathrm{mL}$ ), immediately after production (time 0 ) and after 6 months of storage. $\mathrm{N}=3$. * Statistically significant result compared to negative control.

Similarly, Düsman et al. (2014), evaluating grape juices produced by the same extraction method of this study and obtained from the same farm, but in the harvest of 2012 (one year after the present study), showed that none of the juices, soon after its production, was mutagenic by the micronucleus test. Other studies have not found mutagenicity by Pinot Noir $(2,10$, and $20 \mu \mathrm{L} / \mathrm{mL})$ in Chinese hamster lung fibroblasts (V79) by the comet assay in vitro (Edenharder et al., 2002) nor in concentrated blue grape juice $(0.5 \mathrm{~mL} / \mathrm{Kg})$ by the mouse bone marrow micronucleus assay in vivo (Edenharder et al., 2003).

This non-mutagenic activity might be due to physicochemical analyses and bioactive compounds (Table 1), which indicates the presence of phenolic compounds, anthocyanins, and antioxidant activity in the grape juices.

Genetics and Molecular Research 16 (2): gmr16029670 
Table 1. Physicochemical characteristics and bioactive compounds of integral juices, immediately after production (time 0$)$ and after 6 months of storage ( 6 months).

\begin{tabular}{l|l|c|c|c|c|c|c|c|c}
\hline \multicolumn{2}{l|}{ Groups } & $\mathrm{pH}$ & AC & TSS & TPC & ANT & EC $_{50}$ & TEAC & ${ }^{\circ} \mathrm{Hue}$ \\
\hline \multirow{3}{*}{ Time 0 } & Conv & $2.5 \pm 0.00$ & $0.9 \pm 0.01$ & $11.7 \pm 0.25$ & $155.78 \pm 9.48$ & $9.4 \pm 0.25$ & $73.2 \pm 6.10$ & $9.9 \pm 0.13$ & $15.6 \pm 0.34$ \\
\cline { 2 - 10 } & Org & $3.3 \pm 0.06^{\mathrm{a}}$ & $0.9 \pm 0.01$ & $11.0 \pm 0.00^{\mathrm{a}}$ & $148.4 \pm 3.69$ & $13.1 \pm 0.20^{\mathrm{a}}$ & $76.1 \pm 1.40$ & $9.8 \pm 0.51$ & $12.5 \pm 1.75$ \\
\cline { 2 - 10 } & Org UV-C & $3.3 \pm 0.07^{\mathrm{a}}$ & $0.9 \pm 0.00$ & $11.0 \pm 0.00^{\mathrm{a}}$ & $155.5 \pm 1.92$ & $13.5 \pm 0.45^{\mathrm{a}}$ & $59.6 \pm 6.03^{\mathrm{ab}}$ & $11.9 \pm 0.24^{\mathrm{ab}}$ & $15.6 \pm 0.34$ \\
\hline \multirow{3}{*}{6 months } & Conv & $3.0 \pm 0.01$ & $1.0 \pm 0.04^{\mathrm{a}}$ & $11.7 \pm 0.00$ & $136.7 \pm 12.14^{\mathrm{a}}$ & $6.7 \pm 0.25^{\mathrm{a}}$ & $36.0 \pm 2.59^{\mathrm{a}}$ & $4.6 \pm 0.09^{\mathrm{a}}$ & $5.0 \pm 1.54^{\mathrm{a}}$ \\
\cline { 2 - 10 } & Org & $3.1 \pm 0.00$ & $0.7 \pm 0.03^{\text {bd }}$ & $11.4 \pm 0.14^{\mathrm{b}}$ & $149.5 \pm 3.49$ & $7.2 \pm 1.44^{\mathrm{b}}$ & $33.3 \pm 1.98^{\mathrm{b}}$ & $5.3 \pm 0.07^{\mathrm{bd}}$ & $17.7 \pm 1.07^{\mathrm{bd}}$ \\
\cline { 2 - 9 } & Org UV-C & $3.1 \pm 0.01$ & $0.8 \pm 0.06^{\text {cde }}$ & $11.3 \pm 0.14^{\mathrm{d}}$ & $153.8 \pm 0.80$ & $7.4 \pm 0.15^{\mathrm{c}}$ & $29.6 \pm 2.76^{\mathrm{c}}$ & $4.8 \pm 0.02^{\mathrm{c}}$ & $9.4 \pm 1.59^{\text {cde }}$ \\
\hline
\end{tabular}

Integral juices from conventional grapes (Conv), organic grapes (Org), and organic juice from grapes treated with UV-C (Org UV-C). $\mathrm{N}=3$. AC = acidity - $\mathrm{mg}$ tartaric acid $/ 100 \mathrm{~mL}$ juice; $\mathrm{TSS}=$ total soluble solids $-{ }^{\circ} \mathrm{Brix}$; $\mathrm{TPC}=$ total phenolic compounds - mg gallic acid/100 mL juice; ANT = anthocyanins - mg cyanidin 3-glucoside/100 mL juice; $\mathrm{EC}_{50}=$ quantity of sample required to reduce the initial concentration of DPPH radical by $50 \%-\mathrm{mL}$ juice $/ \mathrm{g}$ $\mathrm{DPPH}$; DPPH = 2,2-diphenyl-1-picrylhydrazyl - mg/g DPPH; TEAC $=$ Trolox equivalent antioxidant activity - $\mu \mathrm{M} /$

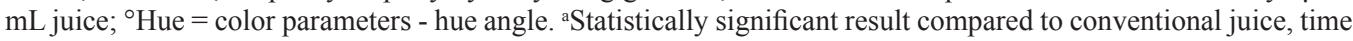

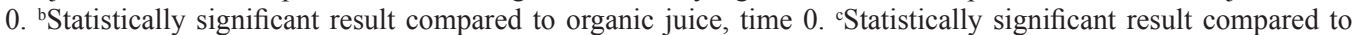
organic juice from grapes treated with UV-C, time 0 . ${ }^{\text {S }}$ tatistically significant result compared to conventional juice,

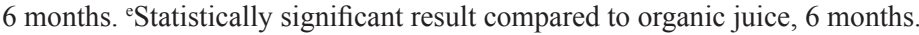

According to Rizzon et al. (1998), juice preparation, especially the temperature and extraction time, regulates the solubility and the intensity of diffusion of substances of the film to the wort, strongly influencing the chemical composition of the final product. Processing is performed to achieve desired results such as killing or inactivating microorganisms or the inactivation of enzymes and anti-nutritional factors (van Boekel and Jongen, 1997). The juices in the current study exhibited $\mathrm{pH}$ values ranging from 2.5 to 3.3 (Table 1), which are unfavorable for microbial growth. These results were similar to data from a study by Rizzon and Miele (1995), where juices of the Concord variety were evaluated, and $\mathrm{pH}$ values of 2.8 to 3.43 were found.

The titratable acidity of grape juices analyzed was also within the values determined by the Brazilian legislation (BRASIL, 2004) $(<0.9 \mathrm{mg}$ tartaric acid/100 mL juice), similar to results found by Rizzon and Miele (1995) $(0.41$ to $1.01 \mathrm{mg}$ tartaric acid/100 mL juice). Only conventional grape juice showed titratable acidity of $1.0 \mathrm{mg}$ tartaric acid/100 mL juice after 6 months of storage.

However, such treatments, especially heat treatment, can result in undesired reactions, mostly of a chemical nature. An oxidation can inactivate antioxidants and vitamins or lead to off-flavors such as rancidity (van Boekel and Jongen, 1997); a reducing sugar may react with amino groups (from free amino acids or lysine residues in proteins) to form low molecular weight compounds that can affect the nutritive value and flavor; the formation of brown pigments may alter the juice color; and the formation of mutagenic compounds may lead to toxicological effects (O'Brien and Morrissey, 1989; van Boekel and Jongen, 1997). These undesirable effects and the formation of harmful compounds possibly were not observed in the present study because the juices were not mutagenic to the Rattus norvegicus hepatoma cells in culture.

In organic farming, chemical substances such as pesticides and synthetic fertilizers are not used to grow crops. The plants are more susceptible to phytopathogens, and this causes the plant to produce higher amounts of phenolic compounds as a means to defend itself. Besides, the ripening period of stemmed plants from organic agriculture is longer than in conventional farming, and because flavonoids are formed during the ripening period, it is believed that the phenolic content of the plant is higher in organically grown plants (Grinder-Pedersen et al.,

Genetics and Molecular Research 16 (2): gmr16029670 
2003). However, in this study, all the juices yielded statistically similar amounts of phenolic compounds (Table 1) regardless of their conventional or organic production. Similar data were found by Tassoni et al. (2013), who found no significant differences between polyphenol levels in conventional and organic farming practices. Furthermore, the mutagenic activities of organic and conventional juices were similar, which corroborates the highlighted by Granato et al. (2016): differences between organic and conventional grape juices are negligible from the nutritional and biochemical perspectives.

Compared to common conventional farming practices, organic soil management practices and chemical control of weeds provide a higher yield due to reduced competition for soil and water reserves given the reduced number of weeds and improved soil physical properties (Susaj et al., 2013). However, in the present study, the juice from conventional grapes had statistically more sugars (total soluble solids) than the juice from organic grapes at time 0 (conventional $=11.7 \pm 0.25^{\circ} \mathrm{Brix}$ and organic $\left.=11.0 \pm 0.00^{\circ} \mathrm{Brix}\right)$. But, all conventional and organic juices studied had total soluble solid levels between 11.0 and $11.7^{\circ}$ Brix values, smaller than those required by the Brazilian legislation (BRASIL, 2004) $\left(>14^{\circ}\right.$ Brix). These levels of total soluble solids can be attributed to factors such as soil, climate, and time of harvest, which may have promoted the dilution of solids as suggested by Bueno et al. (2002).

In the present study, the phenolic compound content and mutagenic activity did not differ with UV-C irradiation of organic grapes, at time 0. Düsman et al. (2014) also showed that the post-harvest treatment of organic and conventional grapes with UV-C did not alter the mutagenicity in HTC cells. In a study by Cantos et al. (2001), the UV-C irradiation (510 W) of grapes after harvesting increased the resveratrol content eleven times and in a study by González-Barrio et al. (2009), the phenol concentration increased 35 times. Thus, although the amounts of phenolic compounds did not change in the present study, the antioxidant potential at time 0 was more efficient in the juices from organic grapes treated with UV-C than in the untreated organic grapes $\left(\mathrm{EC}_{50}\right.$ organic $\mathrm{UV}-\mathrm{C}=59.6 \pm 6.03 \mathrm{mg} / \mathrm{mL}$ juice and $\mathrm{EC}_{50}$ organic $=$ $76.12 \pm 1.40 \mathrm{mg} / \mathrm{mL}$ juice; TEAC organic UV-C $=11.9 \pm 0.24 \mathrm{mg} / \mathrm{mL}$ juice and TEAC organic $=9.8 \pm 0.51 \mu \mathrm{M} / \mathrm{mL}$ juice). In addition to the lack of formation of mutagenic compounds, irradiation of organic grapes increased their antioxidant capacity.

Despite this, after 6 months of storage, the conventional grape juice had statistically reduced levels of phenolic compounds (time $0=155.78 \pm 9.48 \mathrm{mg} / 100 \mathrm{~mL}$ juice and 6 months $=136.7 \pm 12.14 \mathrm{mg} / 100 \mathrm{~mL}$ juice) and anthocyanins (time $0=9.46 \pm 0.25 \mathrm{mg} / 100 \mathrm{~mL}$ juice and 6 months $=6.7 \pm 0.25 \mathrm{mg} / 100 \mathrm{~mL}$ juice) due to the storage and degradation of these compounds. The anthocyanin contents were also statistically reduced in the organic juice $(13.1 \pm 0.20 \mathrm{mg} / 100 \mathrm{~mL}$ juice to $7.2 \pm 1.4 \mathrm{mg} / 100 \mathrm{~mL}$ juice$)$ and organic juice from grapes treated with UV-C (13.5 $\pm 0.45 \mathrm{mg} / 100 \mathrm{~mL}$ juice to $7.4 \pm 0.15 \mathrm{mg} / 100 \mathrm{~mL}$ juice). According to Malacrida and Motta (2005), the reduction in anthocyanin content in fruit juices can be attributed to oxidation, which can start during the juice extraction process and continue during the storage period.

Alterations in anthocyanin content can influence the aroma, flavor, and color of juice (Malacrida and Motta, 2005). In this study, the reduction of color was statistically significant in conventional and organic juices from grapes treated with UV-C (Table 1).

In organic juices and organic juices from grapes treated with UV-C, the levels of phenolic acids remained stable during the storage process (Table 1), which rules out an imbalance in the acid dissociation as a function of storage time. After 10 months of storage, Gollücke et al. (2009) found high phenolic compound levels, stability, and antioxidant activity

Genetics and Molecular Research 16 (2): gmr16029670 
maintenance in the Concord grape juice. The stability of phenolic compounds in the present study agreed with a lack of mutagenic activity because previous studies (Stagos et al., 2006) have shown that the oxidation of flavonoids may result in the formation of $\mathrm{H}_{2} \mathrm{O}_{2}$, which may cause DNA damage.

Furthermore, the oxidation of Vitamin C, present in grape juice, is dependent on factors such as light, temperature, the presence of oxidizing enzymes or metal catalysts and can result in mutagenic effects, as shown by Franke et al. (2004). However, the grape juice tested here exhibited no mutagenic potential, possibly due to the high quantity of phenolic compounds (Table 1), which may protect the food from easily oxidizable compounds and inhibit the oxidation of Vitamin C, carotenoids, and unsaturated fatty acids (Sá, 2012).

Moreover, despite the alteration in some physicochemical parameters, the juices showed no cytotoxic potential. The CBPI results (Table 2) indicate that this parameter was statistically similar to the negative control in all juice concentrations evaluated. The absence of toxicological effects has been confirmed for grape seed extracts in vivo (Lluís et al., 2011) and by grape juices in vitro (Düsman et al., 2014).

Table 2. Cytokinesis-blocked proliferation index (CBPI) and percentage of cytostasis compared to the negative control.

\begin{tabular}{|c|c|c|c|c|c|}
\hline \multirow{2}{*}{\multicolumn{2}{|c|}{ Groups }} & \multicolumn{2}{|c|}{ CBPI (average \pm SD) } & \multicolumn{2}{|c|}{$\%$ Cytostasis } \\
\hline & & Time 0 & 6 months & Time 0 & 6 months \\
\hline \multicolumn{2}{|l|}{$\mathrm{CO}$} & $1.67 \pm 0.04$ & $1.47 \pm 0.09$ & - & - \\
\hline \multicolumn{2}{|l|}{ DOX } & $1.53 \pm 0.07$ & $1.54 \pm 0.01$ & 20.89 & -14.89 \\
\hline \multirow[t]{3}{*}{ Conv } & $2 \mu \mathrm{L} / \mathrm{mL}$ & $1.73 \pm 0.01$ & $1.60 \pm 0.04$ & -8.95 & -27.66 \\
\hline & $10 \mu \mathrm{L} / \mathrm{mL}$ & $1.73 \pm 0.04$ & $1.61 \pm 0.06$ & -8.95 & -29.78 \\
\hline & $20 \mu \mathrm{L} / \mathrm{mL}$ & $1.65 \pm 0.08$ & $1.62 \pm 0.11$ & 2.98 & -31.91 \\
\hline \multirow[t]{3}{*}{ Org } & $2 \mu \mathrm{L} / \mathrm{mL}$ & $1.59 \pm 0.06$ & $1.57 \pm 0.07$ & 11.94 & -21.27 \\
\hline & $10 \mu \mathrm{L} / \mathrm{mL}$ & $1.69 \pm 0.03$ & $1.65 \pm 0.01$ & -2.98 & -38.29 \\
\hline & $20 \mu \mathrm{L} / \mathrm{mL}$ & $1.74 \pm 0.08$ & $1.64 \pm 0.04$ & -10.44 & -36.17 \\
\hline \multirow[t]{3}{*}{ Org UV-C } & $2 \mu \mathrm{L} / \mathrm{mL}$ & $1.60 \pm 0.10$ & $1.43 \pm 0.06$ & 10.44 & 8.51 \\
\hline & $10 \mu \mathrm{L} / \mathrm{mL}$ & $1.64 \pm 0.01$ & $1.58 \pm 0.09$ & 4.47 & -23.40 \\
\hline & $20 \mu \mathrm{L} / \mathrm{mL}$ & $1.62 \pm 0.08$ & $1.64 \pm 0.04^{\mathrm{a}}$ & 7.46 & -36.17 \\
\hline
\end{tabular}

CO: negative control (20 $\mu \mathrm{L}$ PBS); DOX: $0.2 \mu \mathrm{g}$ Doxorubicin $/ \mathrm{mL}$; Conv: integral grape juice from conventional grapes; Org: organic grapes; Org UV-C: organic grapes after treatment with UV-C; Time 0: 2, 10, and $20 \mu \mathrm{L} /$ $\mathrm{mL}$, immediately after production; 6 months: after 6 months of storage. $\mathrm{N}=3 . \mathrm{SD}=$ standard deviation. Negative

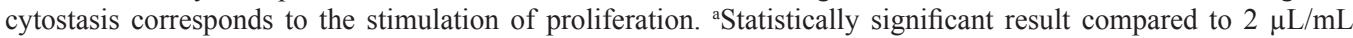
organic juice from grapes treated with UV-C at 6 months.

In general, juice induced cell proliferation in this study, indicated by a negative cytostasis percentage (Table 2). The induction of cell proliferation is possibly due to the vitamins and sugar content (total soluble solids) present in the juice, while the total soluble solids showed a positive correlation with CBPI in most of the juice concentrations evaluated here. Wang et al. (2014) showed that when Vitamin C, one vitamin present in grapes, is added at specific concentrations in the culture medium, it acts as a growth promoter and increases cell proliferation and DNA synthesis. At time $0,20 \mu \mathrm{L} / \mathrm{mL}$ of the conventional juice, $2 \mu \mathrm{L} / \mathrm{mL}$ of the organic grape juice, and three concentrations of the organic juice from grapes treated with UV-C indicated cytostatic cells (conventional $20 \mu \mathrm{L} / \mathrm{mL}: 2.98 \%$, organic $2 \mu \mathrm{L} / \mathrm{mL}: 11.94 \%$, organic UV-C $2 \mu \mathrm{L} / \mathrm{mL}: 10.44 \%, 10 \mu \mathrm{L} / \mathrm{mL}: 4.47 \%$, and $20 \mu \mathrm{L} / \mathrm{mL}: 7.46 \%$ ). However, these percentages were much lower than the positive control, which showed approximately $20.89 \%$ cytostasis. At 6 months, only the $2 \mu \mathrm{L} / \mathrm{mL}$ concentration of organic juice from grapes treated with UV-C indicated $8.51 \%$ cytostatic cells. The predominance of cytostatic HTC cells

Genetics and Molecular Research 16 (2): gmr16029670 
in groups of juice that grapes were treated with UV-C may be due to the effect of UV-C irradiation, which stimulates the production of resveratrol in postharvest grapes (Cantos et al., 2001). However, according to Stocco et al. (2012), phytoalexin has protective effects on cells at low concentrations and can sensitize the cells at high concentrations.

The results of this study show that the process of grape juice production and the new technology in this area, such as the use of UV-C irradiation, altered the levels of anthocyanins and antioxidant activity and did not cause cytotoxic and mutagenic activity. Furthermore, despite nutraceutical reductions, juices stored for 6 months did not induce the formation of cytotoxic and mutagenic substances.

Combined with the proven nutritional benefit of the consumption of grapes to human health, the data from this study show that grape juice has great nutraceutical potential regardless of the type of farming used (conventional or organic) and is not harmful to Rattus norvegicus hepatoma cells, which have a metabolism similar to that of human cells. These results supply some insight into the effects of food processing technology and, together with physicochemical analysis data, ensure the quality and safety of consumption of these juices by humans.

\section{Conflicts of interest}

The authors declare no conflict of interest.

\section{ACKNOWLEDGMENTS}

The authors would like to thank Coordenação de Aperfeiçoamento de Pessoal de Nível Superior (CAPES), the Laboratory of Mutagenesis and Environmental Monitoring at the State University of Maringá (UEM), the Laboratory of Food Biochemistry, the Unit of Teaching, Research and Extension of Fruits, Vegetables, and Beverages at the Federal Technological University of Paraná (UTFPR) Francisco Beltrão, Paraná, Brazil.

\section{REFERENCES}

Ali K, Maltese F, Choi YH and Verpoorte R (2010). Metabolic constituents of grapevine and grape-derived products. Phytochem. Rev. 9: 357-378. https://doi.org/10.1007/s11101-009-9158-0

Brand-Wiliams W, Cuvelier ME and Berset C (1995). Use of a free radical method to evaluate antioxidant activity. Food Sci. Technol. (Campinas) 28: 25-30.

BRASIL (2004). Ministério da Agricultura Pecuária e Abastecimento. Portaria No. 55 de 27 de julho de 2004. Dispõe sobre Normas referentes à complementação dos padrões de identidade e qualidade do vinho e dos derivados da uva e do vinho. Diário Oficial da União, Brasília, Distrito Federal, Brazil.

Bueno SM, Lopes MRV, Graciano RAS, Fernández ECB, et al. (2002). Avaliação da qualidade de polpas de frutas congeladas. Rev. Inst. Adolfo Lutz 62: 121-126.

Cantos E, Espín JC and Tomás-Barberán FA (2001). Postharvest induction modeling method using UV irradiation pulses for obtaining resveratrol-enriched table grapes: a new "functional" fruit? J. Agric. Food Chem. 49: 5052-5058. https://doi.org/10.1021/jf010366a

COM - Committee on Mutagenicity of Chemicals in Food, Consumers Products, and the Environment (2011). Guidance on a strategy for genotoxicity testing of chemical substances. Available at [http://www.iacom.org.uk/guidstate/ documents/COMGuidanceFINAL2.pdf] Accessed March 15, 2017.

Düsman E, de Almeida IV, Lucchetta L and Vicentini VEP (2014). Effect of processing, post-harvest irradiation, and production system on the cytotoxicity and mutagenicity of Vitis labrusca L. juices in HTC cells. PLoS One 9: e107974. https://doi.org/10.1371/journal.pone.0107974

Genetics and Molecular Research 16 (2): gmr16029670 
Edenharder R, Sager JW, Glatt H, Muckel E, et al. (2002). Protection by beverages, fruits, vegetables, herbs, and flavonoids against genotoxicity of 2-acetylaminofluorene and 2-amino-1-methyl-6-phenylimidazo[4,5-b]pyridine (PhIP) in metabolically competent V79 cells. Mutat. Res. 521: 57-72. https://doi.org/10.1016/S1383-5718(02)00212-7

Edenharder R, Krieg H, Köttgen V and Platt KL (2003). Inhibition of clastogenicity of benzo[a]pyrene and of its trans-7,8dihydrodiol in mice in vivo by fruits, vegetables, and flavonoids. Mutat. Res. 537: 169-181. https://doi.org/10.1016/ $\underline{\text { S1383-5718(03)00078-0 }}$

Fenech M (2000). The in vitro micronucleus technique. Mutat. Res. 455: 81-95. https://doi.org/10.1016/S0027$\underline{5107(00) 00065-8}$

Franke SIR, Ckless K, Silveira JD, Rubensam G, et al. (2004). Study of antioxidant and mutagenic activity of different orange juices. Food Chem. 88: 45-55. https://doi.org/10.1016/j.foodchem.2004.01.021

Gollücke APB, Catharino RR, Souza JC, Eberlin MN, et al. (2009). Evolution of major phenolic components and radical scavenging activity of grape juices through concentration process and storage. Food Chem. 112: 868-873. https://doi. org/10.1016/j.foodchem.2008.06.060

González-Barrio R, Vidal-Guevara ML, Tomás-Barberán FA and Espín JC (2009). Preparation of a resveratrol-enriched grape juice based on ultravioleta C-treated berries. Innov. Food Sci. Emerg. Technol. 10: 374-382. https://doi. org/10.1016/j.ifset.2009.01.004

Granato D, Carrapeiro MM, Fogliano V and Ruth SM (2016). Effects of geographical origin, varietal and farming system on the chemical composition and functional properties of purple grape juices: A Review. Trends Food Sci. Technol. 52: 31-48. https://doi.org/10.1016/j.tifs.2016.03.013

Grinder-Pedersen L, Rasmussen SE, Bügel S, Jørgensen LV, et al. (2003). Effect of diets based on foods from conventional versus organic production on intake and excretion of flavonoids and markers of antioxidative defense in humans. $J$. Agric. Food Chem. 51: 5671-5676. https://doi.org/10.1021/jf030217n

Instituto Adolfo Lutz (2008). Normas Analíticas do Instituto Adolfo Lutz. Métodos químicos e físicos para análise de alimentos. IMESP, São Paulo-Brazil.

Kalinova J and Vrchotova N (2011). The influence of organic and conventional crop management, variety and year on the yield and flavonoid level in common buckwheat groats. Food Chem. 127: 602-608. https://doi.org/10.1016/j. foodchem.2011.01.050

Kaya B, Creus A, Velázquez A, Yanikoğlu A, et al. (2002). Genotoxicity is modulated by ascorbic acid. Studies using the wing spot test in Drosophila. Mutat. Res. 520: 93-101. https://doi.org/10.1016/S1383-5718(02)00173-0

Lee J, Durst RW and Wrolstad RE (2005). Determination of total monomeric anthocyanin pigment content of fruit juices, beverages, natural colorants, and wines by the $\mathrm{pH}$ differential method: collaborative study. J. AOAC Int. 88: 12691278 .

Lluís L, Muñoz M, Nogués MR, Sánchez-Martos V, et al. (2011). Toxicology evaluation of a procyanidin-rich extract from grape skins and seeds. Food Chem. Toxicol. 49: 1450-1454. https://doi.org/10.1016/j.fct.2011.03.042

Malacrida CR and Motta S (2005). Compostos fenólicos totais e antocianinas em suco de uva. Food Sci. Technol. (Campinas) 25: 659-664. https://doi.org/10.1590/S0101-20612005000400006

Malacrida CR and Motta S (2006). Antocianinas em suco de uva: composição e estabilidade. Bol. Cent. Pesqui. Process. Aliment. 24: 59-82. https://doi.org/10.5380/cep.v24i1.5294

Melo PS, Arrivetti LdeO, Alencar SM and Skibsted LH (2016). Antioxidative and prooxidative effects in food lipids and synergism with $\alpha$-tocopherol of açaí seed extracts and grape rachis extracts. Food Chem. 213: 440-449. https://doi. org/10.1016/j.foodchem.2016.06.101

Nassiri-Asl M and Hosseinzadeh H (2016). Review of the pharmacological effects os Vitis vinifera (Grape) and its bioactive constituintes: an update. Phytother. Res. 30: 1392-1403. https://doi.org/10.1002/ptr.5644

O'Brien J and Morrissey PA (1989). Nutritional and toxicological aspects of the Maillard browning reaction in foods. Crit. Rev. Food Sci. Nutr. 28: 211-248. https://doi.org/10.1080/10408398909527499

OECD (2010). Guideline for the Testing of Chemicals - In Vitro Mammalian Cell Micronucleus Test. Available at [http:// www.oecd.org] Accessed March 15, 2017.

Olsson ME, Andersson CS, Oredsson S, Berglund RH, et al. (2006). Antioxidant levels and inhibition of cancer cell proliferation in vitro by extracts from organically and conventionally cultivated strawberries. J. Agric. Food Chem. 54: 1248-1255. https://doi.org/10.1021/jf0524776

Rizzon LA and Miele A (1995). Características analíticas de sucos de uva elaborados no Rio Grande do Sul. Bol. Soc. Bras. Food Sci. Technol. (Campinas) 29: 129-133.

Rizzon LA, Manfroi V and Meneguzzo J (1998). Elaboração de suco de uva na propriedade vitícola. Embrapa Uva e Vinho, Bento Gonçalves-Rio Grande do Sul-Brazil.

Rufino MSM, Alves RE, Brito ES, Morais SM, et al. (2007). Metodologia Científica: determinação da atividade

Genetics and Molecular Research 16 (2): gmr16029670 
antioxidante total em frutas pela captura do radical livre DPPH. Embrapa Agroindustrial Tropical, Fortaleza-Brazil. Sá NMSM (2012). Efeito do processamento sobre a composição de compostos fenólicos presentes no suco de caju. Master's dissertation. Federal University of Ceará, Fortaleza, Brazil. Avaliable at [http://www.repositorio.ufc.br/ bitstream/riufc/4096/1/2012_dis_nmsmsa.pdf.] Accessed March 15, 2017.

Salvadori DMF, Ribeiro LR and Fenech M (2003). Teste do micronúcleo em células humanas in vitro. In: Mutagênese Ambiental (Ribeiro LR, Salvadori DMF and Marques EK, eds.). ULBRA, Canoas-Rio Grande do Sul-Brazil.

Singh CK, Siddiqui IA, El-Abd S, Mukhtar H, et al. (2016). Combination chemoprevention with grape antioxidants. Mol. Nutr. Food Res. 60: 1406-1415. https://doi.org/10.1002/mnfr.201500945

Singleton VL and Rossi JAJR (1965). Colorimetry of total phenolics with phosphomolybdic-phosphotungstic acid reagents. Am. J. Enol. Vitic. 16: 144-158.

Stagos D, Kazantzoglou G, Theofanidou D, Kakalopoulou G, et al. (2006). Activity of grape extracts from Greek varieties of Vitis vinifera against mutagenicity induced by bleomycin and hydrogen peroxide in Salmonella typhimurium strain TA102. Mutat. Res. 609: 165-175. https://doi.org/10.1016/j.mrgentox.2006.06.032

Stocco B, Toledo K, Salvador M, Paulo M, et al. (2012). Dose-dependent effect of resveratrol on bladder cancer cells: chemoprevention and oxidative stress. Maturitas 72: 72-78. https://doi.org/10.1016/j.maturitas.2012.02.004

Susaj L, Susaj E, Belegu M, Mustafa S, et al. (2013). Effects of different weed management practices on production and quality of wine grape cultivar Kallmet in North-Western Albania. J. Food Agric. Environ. 11: 379-382.

Tagliazucchi D, Verzelloni E, Helal A and Conte A (2013). Effect of grape variety on the evolution of sugars, hydroxymethylfurfural, polyphenols and antioxidant activity during grape must cooking. Int. J. Food Sci. Technol. 48: 808-816. https://doi.org/10.1111/ijfs. 12031

Tassoni A, Tango N and Ferri M (2013). Comparison of biogenic amine and polyphenol profiles of grape berries and wines obtained following conventional, organic and biodynamic agricultural and oenological practices. Food Chem. 139: 405-413. https://doi.org/10.1016/j.foodchem.2013.01.041

van Boekel MA and Jongen WMF (1997). Product quality and food processing: how to quantify the healthiness of a product. Cancer Lett. 114: 65-69. https://doi.org/10.1016/S0304-3835(97)04627-2

Wang J, Cao H, Xue X, Fan C, et al. (2014). Effect of vitamin C on growth of caprine spermatogonial stem cells in vitro. Theriogenology 81: 545-555. https://doi.org/10.1016/j.theriogenology.2013.11.007

Zhang Y, Hu XS, Chen F, Wu JH, et al. (2008). Stability and color characteristics of PEF treated cyaniding-3-glicoside during storage. Food Chem. 106: 669-679. https://doi.org/10.1016/j.foodchem.2007.06.030

Genetics and Molecular Research 16 (2): gmr16029670 